\title{
A Study on the Potential of Cow Dung Waste as an Environmentally Friendly Alternative Energy Source
}

\author{
Ratminingsih ${ }^{1, *}$ Jumadi $^{2}$ \\ ${ }^{1,2}$ Science Education Department, Graduate School Program, Yogyakarta State University, Indonesia \\ *Corresponding author. Email: ratmi25@gmail.com
}

\begin{abstract}
Cow dung is a very serious problem for people around the farm. The problem is often caused by cow dung which is not handled professionally. Its existence pollutes the environment, disturbs the scenery, and can be a vector of disease. The purpose of this study is to provide an overview of the potential of cow dung waste as an environmentally friendly alternative energy source. This study used a descriptive content analysis study method. The study found that cow dung waste can be processed into biogas. The process is through fermenting the cow dung in a biogas reactor. Biogas has various benefits as an alternative energy source, namely replacing LPG gas and kerosene, power generation, water pump driving, and a substitute for gasoline fuel. The eco-friendly concept boils down to optimizing the use of natural resources while maintaining environmental sustainability. The potential for the utilization of cow dung waste can overcome public complaints about the scarcity of LPG gas and kerosene, expensive electricity bills, fuel, and cases of environmental pollution due to cow dung waste. It is recommended to provide education to the public about the utilization of cow dung to obtain optimal results.
\end{abstract}

Keywords: Cow Dung Waste, Environmentally Friendly, Alternative Energy Source.

\section{INTRODUCTION}

Currently, Indonesia's food security is mostly supported by the livestock sector. One of them is cow farming. The cow breeding centers in Indonesia include Sekarmojo Village, Pasuruan and Wonosalam District, Jombang and others. The villages are highly potential for the development of cow farms due to large area of land for the livestock along with its feed and the culture of the community that supports it. The large potential of cow farming provides great benefits to support the provision of animal protein but can also make an impact on environmental pollution [1]. The more cows that are raised, the more dung will be produced. Cow dung waste in a large capacity is generally not professionally processed by the community. Disposing of waste to the open land until it piles up creates new problems for the surrounding environment [2]. These problems include unpleasant odors, pollute the environment, and can become vectors of disease [1]. Besides, unmanaged livestock waste produces the largest greenhouse gas emissions, which is around $\pm 18 \%$. Every $1 \mathrm{~kg}$ of cow dung can release about 60 liters of gas emissions into the air. The largest composition is methane gas (CH4) [3].

Cows can produce dung waste in large capacities every day. A cow weighing $454 \mathrm{~kg}$ can produce up to $30 \mathrm{~kg}$ of faecal waste every day. If the farmer has 5 cows, the amount of dung that is produced will reach $150 \mathrm{~kg}$ per day. Farmers tend to throw them on empty land or pile them up at the edge of the pen [1]. The accumulation of cow dung waste in the environment results in decreased environmental quality. This is because the dirt that is disposed of directly is still hot, so it can inhibit plant growth. The application of environmentally appropriate technology to overcome these problems needs to be done gradually to maintain the balance of the production sector with the preservation of the surrounding environment [4].

The application of cow dung waste cultivation to become an environmentally friendly alternative energy source is important to do to reduce the negative impact. This is in line with the concept of 
"Environmentally Friendly Development" which has been proclaimed by the government in the Law of the Republic of Indonesia No. 32 of 2009 concerning Protection and Management of the Environment [4]. Every activity that runs in cow farming needs to pay attention about the impact on the environment and how to solve it. The activity of processing cow dung waste into an alternative energy source is directed not only to support environmental sustainability but also to provide solutions to problems in other sectors.

The development of alternative energy sources is also expected to overcome the scarcity and cost of fossil energy sources in Indonesia. The price of fuel oil and LPG today continues to increase from year to year. The higher the price of fuel oil and LPG make the people become restless. Apart from being expensive, its availability on the market is also increasingly scarce. Many communities, especially those in rural areas, difficult to find it. It is common for children in rural areas do not go to school to look for firewood [5]. This should be concerned by many parties. The development of alternative energy sources with waste-based materials can reduce people's dependence on non-renewable sources [3]. The utilization of cow dung waste can be developed widely, such as for lighting and others. Therefore we need a study that provides an understanding of the public about the potential use of cow dung waste in Indonesia.

This research is a descriptive content analysis study to provide education to the public about the utilization of cow dung waste. This is aimed to obtain a detailed description of the information content of a particular text [6]. The analysis was carried out on various scientific sources regarding the potential of cow dung waste as an alternative energy source in Indonesia. Scientific sources used include national and international scientific journals as well as other sources relevant to the material.

\section{DISCUSSION}

\subsection{Potential of Cow Farming in Indonesia}

The potential for developing cow farms in Indonesia is enormous. Cow breeding centers in Indonesia, among others, are in the Village of Sekarmojo-Pasuruan, Wonosalam-Jombang District, Merauke Regency, and Cangkringan-Sleman and various other areas [1] [4] [5] [7]. These areas are very potential for cow farming because they have natural resources that support animal feed. Besides, the culture of the surrounding community also supports the development of cow farming. One example of the number of cow and buffalo in the Merauke Regency until 2014 was around 33,000 heads [5]. The number of cow in Bali Province from 2013 to 2017 was 525,955 heads [8]. However, not all people in the area have an understanding and awareness to process cow dung waste into alternative energy.

The potential amount of cow dung waste in Indonesia can be seen from the number of cow population. The more cows that are raised, the more capacity for waste dung will be produced. The population of beef cow in Indonesia in 2010 is estimated at 10.8 million heads and 350,000 400,000 dairy cows. This number will continue to increase with the limitation on meat imports by the Minister of Agriculture. One cow can produce about $8-10 \mathrm{~kg}$ of dung per day so that in one year it produces $2.6-3.6$ tons. If one cow on average every day produces $7 \mathrm{~kg}$ of dry dung, the dry cow dung produced in Indonesia is 78.4 million kilograms of dry dung per day [9].

\subsection{Conversion of Waste into Alternative Energy Sources}

Cow dung waste can be processed into an alternative energy source by processing it into biogas. Biogas is a gas that is produced from various kinds of organic waste such as animal dung and biomass waste which is processed in an anaerobic digester or closed room. Animal dung that can be used includes cows, buffaloes, goats, chickens, and other livestock [4].

Biogas contains methane gas $(\mathrm{CH} 4)$ and carbon dioxide $(\mathrm{CO} 2)$. Methane gas in biogas can reach up to $70 \%$ while other gases are produced in small amounts [10]. The concentration of methane gas determines the amount of energy content in biogas. The greater the methane content, the greater the energy content or calorific value. The heating value of pure methane gas is $8900 \mathrm{kcal} / \mathrm{m} 3$ while the heating value after being converted into biogas is around 4800 to 6700 $\mathrm{kcal} / \mathrm{m} 3$. The heating value is high enough so that it can be used for various purposes such as lighting, cooking, moving machines, and others [11]. Biogas quality can be improved by removing carbon dioxide, hydrogen sulfur, and water content [8].

The process of making biogas is very simple. The principle of making biogas is the anaerobic decomposition of organic material to produce gas, mostly methane and carbon dioxide gas. Methane gas has flammable properties [1]. Cow dung waste is put into anaerobic biodigester tube. The anaerobic decomposition process is assisted by several 
microorganisms, including methane bacteria. Microorganisms can work optimally in breaking down organic matter when the temperature is set around $30-50^{\circ} \mathrm{C}$ [3]. The by-product is an organic fertilizer that can be used to fertilize plants [12]. The accumulated gas is collected in the digester and then distributed to the house for further use, for example for lighting and fuel replacement [1]. Each type of livestock produces a different amount of biogas, so the potential of each type of dung is different [8].

The biogas produced from the above processing can be used as an alternative energy source that reduces the impact of fossil fuel use. These alternative energy sources, among others, can be used as electricity generation, a substitute for LPG and kerosene when cooking [13]. Biogas can also be used as a towing power for water pumps and fuel for vehicles at the industrial level [14]. Equality of biogas as an alternative energy source with other energy sources, namely $1 \mathrm{~m}^{3}$ of biogas equivalent to $0.46 \mathrm{~kg}$ of LPG, 0.62 liters of kerosene, 0.52 liter of diesel oil, 0.80 liters of petrol oil, $1.50 \mathrm{~m}^{3}$ of city gas and firewood $3.50 \mathrm{~kg}$ [11]. The efficiency of biogas on a small scale is $55 \%$ for cooking, $24 \%$ for heat engines, and $3 \%$ for lighting [15].

\subsubsection{Substitute for LPG Gas, Kerosene and Firewood}

The existence of scarcity and expensive LPG gas and kerosene can be overcome by utilizing biogas. Household biogas with 2 - 4 livestock or a dung supply of $25 \mathrm{~kg}$ per day is sufficient to use a reactor tube with a capacity of $2500-5000$ liters. The biogas produced is equivalent to 2 liters of kerosene/day. This amount can meet the cooking energy needs of about 6 family members. Research conducted by Dianawati shows that the energy contained in $1 \mathrm{~m}^{3}$ of biogas is $2,000-4,000 \mathrm{kcal}$ or can meet the cooking needs of a family (4-5 people) for 3 hours [16]. To cook $0.5 \mathrm{~kg}$ of rice, an average of 0.15 $\mathrm{m}^{3}$ of biogas is required in 30 minutes. The daily use of the household requires an average of $3 \mathrm{~m}^{3}$ of gas. The use of biogas in the household can reduce the number of family expenses due to the expensive and scarce LPG and kerosene. Even if converted, biogas can replace the expenditure of 2 liters of kerosene or $10 \mathrm{~kg}$ of firewood per day [11].The biogas stove can be modified from an LPG gas stove. How to modify it is by drilling with an iron drill on the Gas Jet or Spuyer injector, with a diameter of $1.5 \mathrm{~mm}$ to $2 \mathrm{~mm}$. The biogas stove can function as an LPG stove [11]. The blue flame color is the same as the LPG gas flame. This indicates that biogas does not produce soot which can pollute household kitchens and cooking rooms. Even the use of biogas in the
Magelang Regency has a gas production potential of $86,690 \mathrm{~m}^{3}$. This value is equivalent to $43,345 \mathrm{~kg}$ of LPG gas or 14,448 $3 \mathrm{~kg}$ LPG cylinders which can be used to cook about 278 households for 1 year [7].

\subsubsection{Power Plants}

Biogas has the potential to be used as a raw material for electricity generation. A study in Argosari Village, Malang Regency shows that a $5 \mathrm{~m}^{3}$ digester with two cows produces $3 \mathrm{~m}^{3}$ of biogas which is enough to power a 400-watt generator for 6 hours [17]. $1 \mathrm{kWh}$ of electricity can be generated by utilizing $0.62-1 \mathrm{~m}^{3}$ of biogas [12]. Biogas can be converted into electrical energy by knowing the amount of cow dung produced every day [8]. Another study in Bali Province, based on the level of cow population from 2013 to 2017 , it was found that the average cow population in Bali Province was 525,955 heads. The potential for biogas from cow dung waste produces electricity of $494,397.7 \mathrm{kWh} /$ day.

\subsubsection{Water Pump Drive Fuel}

The water pump can suck water with biogas fuel because biogas can be used in machines with high compression ratios. The Pertamax fueled water pump can suck water 2 times longer than the water pump fueled by biogas. The amount of water discharge generated by the water pump, both biogas, and pertamax, does not differ much. The ratio of the average time of biogas fuel to Pertamax fuel at different engine speeds is also not much different [3].

\subsubsection{Gasoline Motor Fuel}

The biogas produced in the community service program in Limbangan Village, Banjarnegara Regency can be used for gasoline fuel. Gasoline motor fuel with biogas is very potential because of the high methane content. $\mathrm{H}_{2} \mathrm{~S}$ in high biogas content can pollute the environment so it needs to be purified before being used as fuel. Biogas can be purified using zeolite or using Fe-EDTA (Iron Chelated Solution). Gas purification in this community service program uses iron waste from the lathe industry which is then compressed and put into PVC pipes [11].

Biogas fuel has a high octane number, namely 130. Gasoline has an octane number of 90 to 94 while the best alcohol is only 105 . This shows that biogas can be used in engines with high compression ratios and also prevents the engine from knocking [3]. This is very beneficial for keeping the vehicle durable. 


\subsection{Environmentally Friendly Utilization Concept}

The use of biogas has a role in efforts to preserve the surrounding environment. Cow dung waste that is processed into biogas will reduce the unpleasant smell of livestock dung and prevent the spread of disease [18]. The use of biogas is also expected to reduce biomass waste and reduce the level of global warming [13]. Biogas can also solve environmental problems, such as soil degradation, deforestation, $\mathrm{CO} 2$ emissions, indoor air pollution, organic pollution, [19]. The result of burning fuel from biogas if the result is clean, not smoky like wood charcoal or firewood [3]. The residual waste from the biogas processing process can be used as solid and liquid organic fertilizer to support plant growth [3].

Providing understanding to the community regarding this matter is of course very necessary to get more optimal benefits. Things that need to be done, among others, are to carry out counseling on the dangers of pollution due to cow dung and technical construction of biogas installation. Furthermore, coordinating with cattle breeders to do the occasional arrangement and direct biogas installation. The follow-up of the program can be carried out by giving counseling on the use of biogas as alternative energy both to replace LPG gas, power plants, propulsion water pumps and substitute for gasoline [11].

\section{CONCLUSION}

Cow dung waste treatment as an alternative energy source can be used as a substitute for kerosene and LPG gas, power plants, water pumps, and gasoline replacement fuel. Utilization of cow dung has a positive impact on the surrounding environment because it can reduce environmental pollution and global warming. It is recommended to provide education to the public about the utilization of cow dung to obtain optimal results.

\section{ACKNOWLEDGMENTS}

The author would like to thank the Science Education Department, Graduate School Program, Yogyakarta State University for supporting this research.

\section{REFERENCES}

[1] A. Fathurrohman, M. Aniar Hari S, and M. Awaludin Adam, "Persepsi peternak sapi dalam pemanfaatan kotoran sapi menjadi bi-ogas di
Desa Sekarmojo Purwosari Pasuruan," J. IlmuIlmu Peternak., 2015.

[2] S. Huda and W. Wikanta, "Pemanfaatan Limbah Kotoran Sapi Menjadi Pupuk Organik Sebagai Upaya Mendukung Usaha Peternakan Sapi Potong di Kelompok Tani Ternak Mandiri Jaya Desa Moropelang Kecamatan Babat Kabupaten Lamongan," AKSIOLOGIYA J. Pengabdi. Kpd. Masy., 2016.

[3] A. W. Perdana and S. Wahyuni, "Penggunaan Bahan Bakar Biogas sebagai Energi Penggerak Mula Pompa Air Model CCWP-30," Jurnal Rekayasa Teknologi., 2012.

[4] L. H. Damanik, A. H. Husodo, and T. Gunawan, "Pemanfaatan Feses Ternak Sapi sebagai Energi Alternatif Biogas bagi Rumah Tangga dan Dampaknya Terhadap Lingkungan," Jurnal Teknosains., 2014.

[5] Y. Buyang, I. D. Palittin, R. S. Waremra, J. P. Kimia, J. P. Fisika, and U. Musamus, "Pengganti Bahan Bakar Minyak Utilization of Cow Dung as Energy Resource,",. Dharma Raflesia Unib, 2019.

[6] F. Munirah, “Analisis Isi Deskriptif Rubrik ' Xp Re Si ' Harian Kaltim Post Periode Maret-April 2013," eJournal Ilmu Komun., 2015.

[7] A. B. Yunanda, G. Sarya, and B. Sutriono, "Alternatif Pengganti Gas LPG pada Kompor di Wonosalam," Jurnal Pengabdian LPPM Untag Surabaya., 2016.

[8] M. C. Santoso, I. A. D. Giriantari, and W. G. Ariastina, "Studi Pemanfaatan Kotoran Ternak untuk Pembangkit Listrik Tenaga Biogas di Bali," Spektrum., 2019.

[9] M. Agus and K. Budiyanto, "Mendukung Pertanian Organik di Desa Sumbersari," GAMMA., 2011.

[10] H. Insam, M. Gómez-Brandón, and J. Ascher, "Dung-based biogas fermentation residues Friend or foe of soil fertility?," Soil Biol. Biochem., 2015.

[11] Sunaryo, "Rancang Bangun Reaktor Biogas untuk Pemanfaatan Limbah Kotoran Ternak Sapi di Desa Limbangan Kabupaten Banjarnegara," Jurnal Ppkm Unsiq., 2014.

[12] S. y. S. S. Z. B.Satata, "Pemanfaatan Kotoran Sapi sebagai Sumber Biogas," J. Udayana Mengabdi., 2016. 
[13] R. P. Dewi and M. Kholik, "Kajian Potensi Pemanfaatan Biogas sebagai Salah Satu Sumber Energi Alternatif di Wilayah Magelang," J. Mech. Eng., 2018.

[14] G. P. Minde, S. S. Magdum, and V. Kalyanraman, "Biogas as a Sustainable Alternative for Current Energy Need of India," J. Sustain. Energy Environ., 2013.

[15]V. Tumwesige, D. Fulford, and G. C. Davidson, "Biogas Appliances in Sub-Sahara Africa," Biomass and Bioenergy., 2014.

[16] M. Dianawati and S. L. Mulijanti, "Peluang Pengembangan Biogas Di Sentra Sapi Perah," J. Penelitian dan Pengembangan Pertanian., 2016.

[17] A. U. Farahdiba, A. Ramdhaniati, and E. S. Soedjono, "Teknologi dan Manajemen Program Biogas sebagai Salah Satu Energi Alternatif yang Berkelanjutan di Kabupaten Malang," J. Inovasi dan Kewirausahaan., 2014.

[18] E. R. Orskov, K. Yongabi Anchang, M. Subedi, and J. Smith, "Overview of Holistic Application of Biogas for Small Scale Farmers in SubSaharan Africa," Biomass and Bioenergy., 2014.

[19] M. A. Pereira-Querol, L. Seppänen, and J. Virkkunen, "Exploring the Developmental Possibilities of Environmental Activities: OnFarm Biogas Production," Environment Science Policy., 2014. 